\title{
CHARACTERISTICS OF A $\beta-1,4-D$ ENDOGLUCANASE FROM TRICHODERMA VIRENS WHOLLY APPLIED IN A PALM-FRUIT HUSK-BASED DIET FOR POULTRY LAYERS
}

\author{
Olubusola A. Odeniyi ${ }^{1^{*}}$, Anthony A. Onilude ${ }^{1}$, Maria A. Ayodele ${ }^{2}$ \\ ${ }^{1}$ Microbial Physiology and Biochemistry Research, Department of Microbiology, University of Ibadan, Ibadan, Nigeria; \\ ${ }^{2}$ Germplasm Health Unit, International Institute of Tropical Agriculture, Ibadan, Nigeria.
}

Submitted: May 22, 2010; Returned to authors for corrections: January 26, 2012; Approved: June 07, 2012.

\begin{abstract}
The characteristics of an endoglucanase produced by a Trichoderma virens strain T9 newly isolated from a palm-fruit husk dump site, its physiological characteristics and enzyme production were studied. Whole cells of the depolymerizing-enzyme producing $T$. virens were applied to palm-fruit husk and bird performance characteristics when employed as poultry diet additive were considered. Endoglucanase activity in submerged fermentation was 1.6 nkat. Optimum activity was recorded at $\mathrm{pH} 6.0$ and $55^{\circ} \mathrm{C}$. The enzyme retained $50 \%$ residual glucanase activity at $70^{\circ} \mathrm{C}$ for 10 minutes. $1.0 \%$ Tween- 80 and SDS yielded endoglucanase activity 2.15 times higher than the control. Activity was boosted by $20 \mathrm{mM} \mathrm{Ca}^{2+}(115.0 \%)$; $10 \mathrm{mM} \mathrm{K}^{+}(106.5 \%)$; and was totally inhibited by $1 \mathrm{mM} \mathrm{Hg}^{2+}$. The addition of $T$. virens-fermented palm-fruit husk with other layer feed components on the bird characteristics showed that change in bird weight between the control and test birds were not significantly different $(p>0.05)$ but differed in terms of daily feed ingested $(p<0.05)$. The feed to weight-gain ratio was best with the unmodified palm-fruit husk based diet (8.59). There was no significant difference in the egg weights from modified palm-fruit husk based diet and control $(\mathrm{p}>0.05)$. The shell thickness $(0.64 \mathrm{~mm})$ and yolk content $(23.61 \%)$ were highest in the microbially-modified husk diet.

The alternative to maize based diets proffered by the application of $T$. virens-modified palm-fruit husk in poultry nutrition in terms of bird weight and feed to weight-gain ratio affords the poultry farmer an economic advantage and allows for a greater utilization of the maize in human diets.
\end{abstract}

Key words: Trichoderma virens, endoglucanase, physiology, poultry layer feed

\section{INTRODUCTION}

Plant matter represents a major source of renewable organic matter $(9,19)$. Their composition makes them of veritable biotechnological value (12). In the tropics and around the world, a lot of plant materials are generated all the year round through forestry and agro-industrial practices and thus constitute pollution problems. These problems are generally solved in developing countries through the burning of biomass especially to create space for a new planting season. However, 
these agricultural 'wastes' can be potentially converted to value-added renewable bio-products such as fuels, chemicals, improved animal feeds, and cheap energy sources for fermentation (9). Even though the composition of plant matter is basically crystalline with insoluble cellulose fibrils and surrounding amorphous regions of hexoses and pentoses (22, 23 ), interactions of many bacteria and fungi with them are quite complex.

Microbial degradation of plant structural polysaccharides requires an array of microbial enzymes which work synergistically to achieve effective hydrolysis $(2,3)$. Microorganisms are known to produce these enzymes $(8,13)$ for cellulose hydrolysis. Types of microbial cellulases enlisting different modes of action (3), have been documented to include endoglucanases (carboxymethylcellulases) which hydrolyse the amorphous regions of the plant cellulose structure; exoglucanases (cellobiohydrolases) which progressively cleave units of cellobiose from the crystalline or amorphous ends of the cellulose structure while $\beta$-glucosidases (cellobiases) hydrolyse soluble cellooligosaccharides into glucose units. Many Trichoderma species have been described to possess cellulose-degrading capacities (14, 20, 25, 29).

Palm fruit abounds in the western part of Africa and has been the traditional source of oil, especially for cooking. Palmfruit husk is a readily accessible fibrous substrate obtained after oil extraction from the fruits. This by-product, termed 'Oguso' in the western part of Nigeria, finds application only during massive cooking where it aids the effective combustion of fire wood. Therefore palm oil producers dry up the husk and sell for such purposes only. The alternative use of this husk, in conjunction with $T$. virens, especially in enzyme production and animal nutrition towards ensuring food security is considered in this work.

\section{MATERIALS AND METHODS}

\section{Microorganism and culture conditions}

The Trichoderma virens isolate was obtained from a natural palm-fruit husk dump site within Ibadan metropolis, Nigeria, and cultivated on Potato Dextrose agar (Sigma) at $27 \pm$ $2^{\circ} \mathrm{C}$. The isolate was identified based on morphological characteristics and DNA sequencing as T. virens strain isolate PFH (palm fruit husk) T9. Five day-old cultures were used to inoculate sterilized palm-fruit husk of mesh size $5 \mathrm{~mm}^{2}$ in a solid substrate experimental set-up. The Trichoderma virens isolate was used as an enzyme preparation consisting of whole cells $(7,17)$.

\section{Enzyme production and characterisation}

Screening for the production of endo-1,4- $\beta$ glucanase was effected using a medium described by Yeoh et al. (27). A $3 \mathrm{~mm}$ disc of 5-day old $T$. virens culture was centrally located on an agar plate containing $1.0 \%$ cellulose and $4.5 \% \mathrm{w} / \mathrm{v}$ Czapek Dox agar. Plates were flooded after 3 days with hydrochloric acid and iodide mixture $\{(1 \mathrm{ml} 0.1 \mathrm{M} \mathrm{HCl})$ and $(5 \mathrm{ml}$ of $1 \% \mathrm{w} / \mathrm{v}$ $\mathrm{I}_{2}$ and $\left.\left.2 \% \mathrm{w} / \mathrm{V} \mathrm{KI}\right)\right\}$ and the zone of clearing to the fungal diameter recorded. Enzyme production was carried out using submerged fermentation at $27^{\circ} \mathrm{C}$ with orbital shaking at 125 rpm on a rotary Orbit shaker bath, (Lab-line instruments, Illinois, USA). This involved cultivating two $3 \mathrm{~mm}$ plugs of $T$. virens in $50 \mathrm{~mL}$ of culture medium made up of $1 \%$ Carboxymethylcellulose (CMC), $0.14 \% \quad\left(\mathrm{NH}_{4}\right)_{2} \mathrm{SO}_{4}, \quad 0.6 \%$ $\mathrm{K}_{2} \mathrm{HPO}_{4}, 0.20 \% \mathrm{KH}_{2} \mathrm{PO}_{4}$ and $0.01 \% \mathrm{MgSO}_{4} 7 \mathrm{H}_{2} \mathrm{O}$, pH 6.0 in a $250 \mathrm{~mL}$ Erlenmeyer flask. The mycelium was harvested after 4 days of growth from the culture liquid by centrifugation at $2795 \mathrm{Xg}$ using Hermle ${ }^{\circledR}$ centrifuge (Germany). The supernatant was used as crude enzyme for all practical purposes.

\section{Partial purification of Enzyme}

The concentrated extracellular enzyme extract was subjected to ammonium sulphate precipitation, dialysis and column chromatography. Ammonium sulphate was added up to $80 \%$ saturation; the solution was kept overnight at $4.0{ }^{\circ} \mathrm{C}$ and centrifuged at $13000 \mathrm{Xg}$ for 20 minutes. The enzyme solution was dialysed against $0.1 \mathrm{M}$ citrate phosphate buffer $(\mathrm{pH} 6.0$ ) and loaded onto a $\operatorname{BioRad}^{\circledR} \mathrm{AG} \quad 1-\mathrm{X} 4$ resin previously 
equilibrated with $0.1 \mathrm{M}$ citrate phosphate buffer. The column was washed with the same buffer at a flow rate of $36 \mathrm{mlh}^{-1}$. Three millilitre fractions were collected and those exhibiting enzyme activity were pooled.

\section{Total protein and Enzyme assays}

Soluble protein in culture filtrate was measured by the method of Lowry et al., (1951) using bovine serum albumin as standard. The activity of the Endo-1,4- $\beta$ glucanase extract was determined by the method of Robson and Chambliss (21) and the reducing sugar formed was measured as glucose by the dinitrosalicylic acid procedure of Miller et al. (15). One unit of enzyme activity is expressed as the amount which corresponds to the release of 1 nano mole equivalent of glucose per second under the stated conditions.

\section{Characterisation of T. virens Degrading Activity}

The $\mathrm{pH}$ effect on cellulolytic activity of the isolate $T$. virens was conducted in $0.1 \mathrm{M}$ citrate phosphate assay buffers of $\mathrm{pH} 4.0$ to 9.0 . The same Endo-1, 4- $\beta$ glucanase assay was carried out at various temperatures $(27,40,50,60,70,80,90$ and $100^{\circ} \mathrm{C}$ ) and time intervals of 5, 10, 15, 30 and 60 minutes. The effect of metal salts on enzyme activity was carried out by pre-incubating the enzyme in metal salt solutions of calcium, cobalt $(20 \mathrm{mM})$, potassium, lithium $(10 \mathrm{mM})$ and mercury (1 $\mathrm{mM} \mathrm{Hg} 2+$ ) for 60 minutes and the residual activities determined. To analyse the effect of different surfactants on enzyme activity, $1 \mathrm{ml}$ of $0.05,0.1,0.1,1.0$ and $5.0 \%$ of polyoxyethylene sorbitan mono-oleate (Tween 80), polyethylene glycol p-isooctylphenyl ether (Triton X-100) and Sodium Dodecyl Sulphate (SDS) was incubated with $1 \mathrm{~mL}$ enzyme then assayed using the standard procedure as described above.

\section{Feeding experiment}

Birds: Thirty-six, 26 weeks-old point-of-lay ISA brown birds were purchased from a commercial poultry farm in Ibadan, Nigeria. The birds were distributed into three treatments of 12 birds each, the choice of treatment depending on the feed type and microbial addition. Each treatment was arranged into replicates of 6 birds. They were identified with individual leg rings and randomly assigned with 2 birds per cage. The experiment spanned four weeks.

Fermentation of palm-fruit husk: Multiples of a mixture of $5 \mathrm{~g}$ of palm-fruit husk with a mineral solution (MS) mixture of $10 \mathrm{ml}$ of $1 \%\left(\mathrm{NH}_{4}\right)_{2} \mathrm{SO}_{4}$ and $0.02 \% \mathrm{MgSO}_{4}$ (at a total of $67 \%$ of moisture) were autoclaved. Each flask was inoculated by transferring $3 \mathrm{~mm}$ agar plug excised from the margin of a 5day-old T. virens culture and incubated for 48 hours in a solid substrate fermentation system. The fermented and nonfermented husk substrates were each mixed in a mash with other poultry layer feed components as shown in Table 2 to make bird feed.

Feed: Birds were fed a basal diet in which the maize component was entirely substituted for with palm-fruit husk with or without the addition of T. virens strain isolate PFH T9. The normal feed diet and other feed components were obtained commercially from Amo-Byng ${ }^{\circledR}$ Feed, Awe, Oyo State. Palmfruit husk was obtained after the traditional extraction of oil from the fruit. All birds were allowed free access to feed and water. The analytical composition (26) of both the microbial and non-microbially modified palm-fruit husk diet and control diet is as stated in Table 1.

Table 1. Composition of experimental diets

\begin{tabular}{lccc}
\hline Ingredients & PFH B & PFH C & AMO-BYNG \\
\hline Maize & $\overline{30}$ & $\overline{30}$ & 40 \\
Concentrate (\%) & 30 & 30 & 30 \\
Wheat offal (\%) & $\overline{40}$ & $\overline{40}$ & - \\
Rice husks (\%) & & - \\
Palm-fruit husk (\%) & $4 . v i r e n s$ & - & - \\
Microbial additives & 16.64 & 16.03 & 16.40 \\
Crude protein (\%) & 8.00 & 10.00 & 6.00 \\
Crude fibre (\%) & 8.08 & 10.04 & 5.19 \\
Cellulose & 21.04 & 19.64 & 21.75 \\
Hemicellulose & & & \\
\hline
\end{tabular}

\section{Monitoring of Birds' performance Characteristics:}

Feed consumption and increase in body weight were monitored throughout the duration of the experiment with an electronic 
weighing balance. The egg characteristics considered included weight, yolk and shell characteristics. The experimental data were analysed using an ANOVA test with $\mathrm{p}<0.05$ considered significant. To determine significant differences between treatment groups for substrate, and microbial additive effects, a t-test was done using Graph-pad Prism 4.0 software.

\section{RESULTS}

Screening for ability of $T$. virens isolate to produce endo$1,4-\beta$ glucanase revealed a ratio of cleared zone to fungal diameter of 5.8. Enzyme assay showed an endo-1,4- $\beta$ glucanase activity of $1.6 n k a t$. With increasing $\mathrm{pH}$, the endo$1,4-\beta$ glucanase activity increased gradually between 4.0 and 5.0, then sharply at 6.0 (Figure 1). Beyond this range, enzymatic activities gradually decreased as the $\mathrm{pH}$ approached a neutral then alkali range. Conversely, the growth rate rapidly decreased beyond $\mathrm{pH}$ 4.0. The highest thermal stability exhibited by this enzyme spanned $27^{\circ} \mathrm{C}$ to $40^{\circ} \mathrm{C}$ throughout the incubation periods applied and at $50^{\circ} \mathrm{C}$ up to 10 minutes (Figure 2). Beyond this time, enzymatic activities reduced to $46.7 \%$ after 60 minutes. At $60^{\circ} \mathrm{C}$, percentage residual activity was higher at 5 and 10 minutes $(73.3 \%)$ then reduced at 15 minutes (63\%). After this, as temperature increased, values consistently reduced. A residual glucanase activity of $50 \%$ was realized at $70^{\circ} \mathrm{C}$ and 10 minutes. The least response to changes (23.3\%) was demonstrated at $90^{\circ} \mathrm{C}$ for 5 minutes. Complete inactivation was recorded beyond this temperature and time regime.

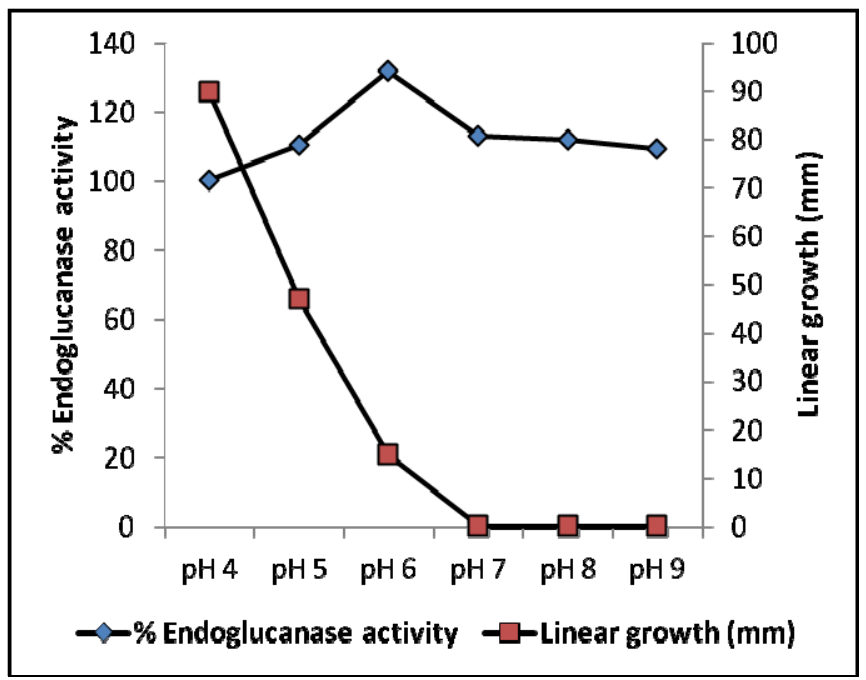

Figure 1. Effect of $\mathrm{pH}$ on the growth of $T$. virens isolate and its endo-1,4- $\beta$ glucanase activity.

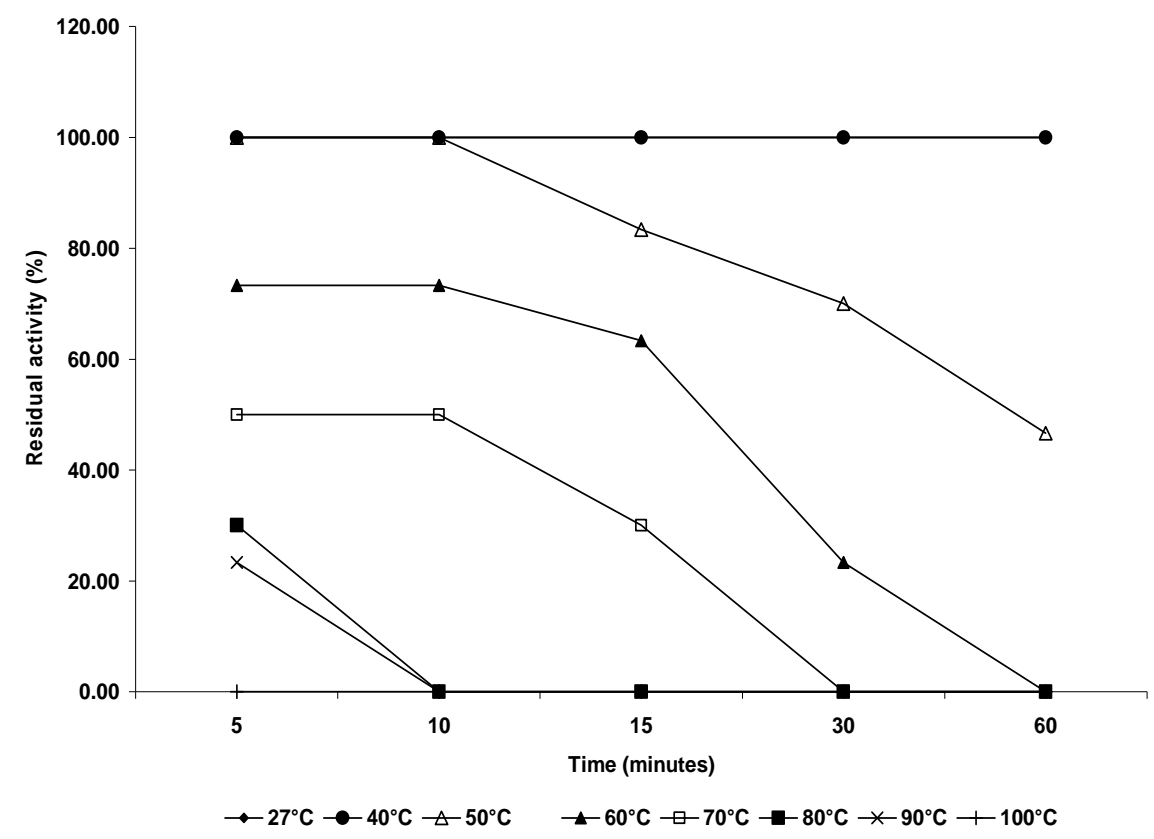

Figure 2. Response of endo-1,4- $\beta$ glucanase to different incubation temperatures relative to time. 
Cobalt ion repressed the activities of the endo-1,4- $\beta$ glucanase $\left(37.5 \%\right.$ ) while $\mathrm{Hg}^{2+}$ totally inhibited it (Figure 3 ). $\mathrm{K}^{+}$ and $\mathrm{Ca}^{2+}$ raised activity by $6.5 \%$ and $15 \%$ respectively. Tween80 and SDS at $1.0 \%$ concentration gave the highest endo- $1,4-\beta$ glucanase activity (3.4nkat), followed by values at $0.5 \%$
(Figure 4). Triton X-100 yielded its best endo-1,4- $\beta$ glucanase activity at $0.5 \%$ concentration. A purification factor of 6.57 with $369.03 \%$ yield was achieved with the endo-1,4- $\beta$ glucanase showing a specific activity of $3.99 \mathrm{nkat} / \mathrm{mg}$ protein (Table 2).

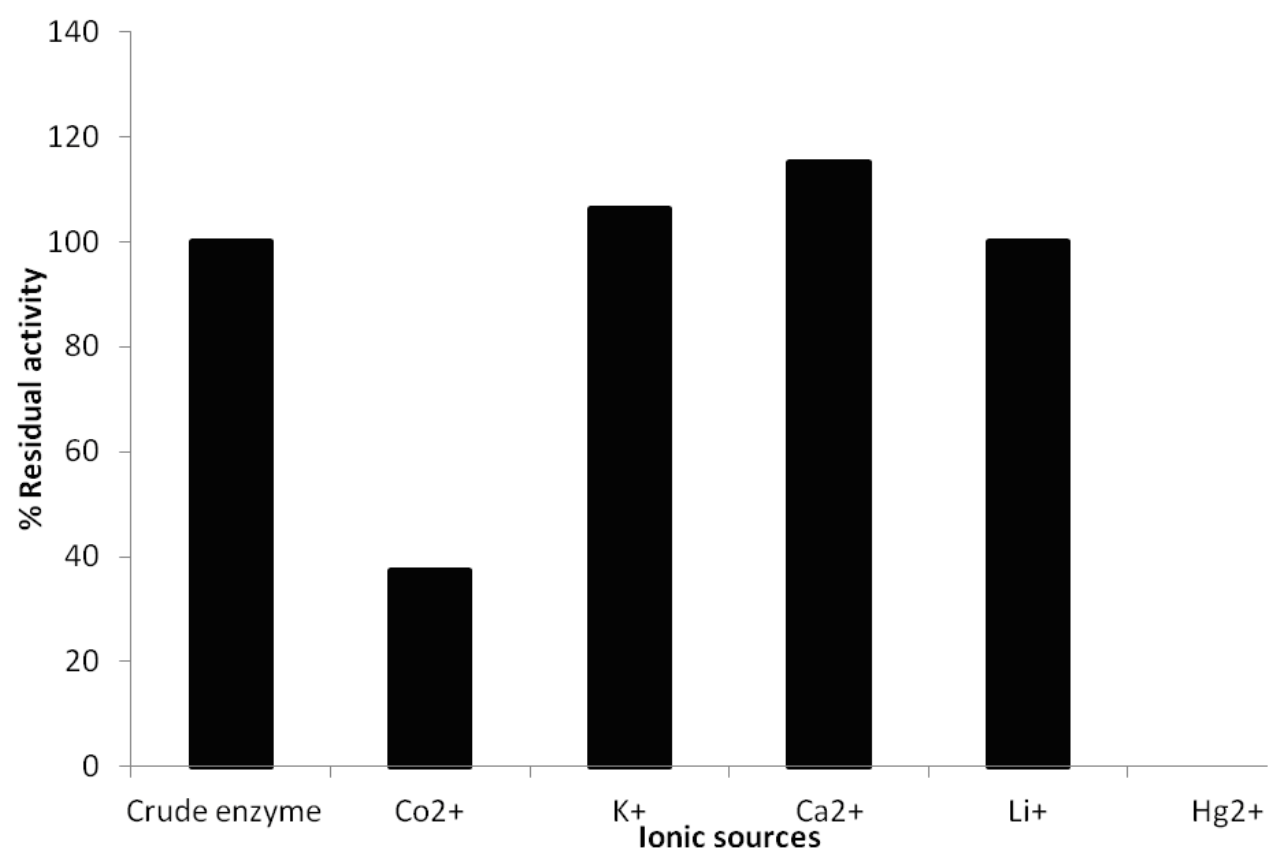

Figure 3. Effect of different ionic compounds on the endo-1,4- $\beta$ glucanase activities of T. virens isolate PFHT9

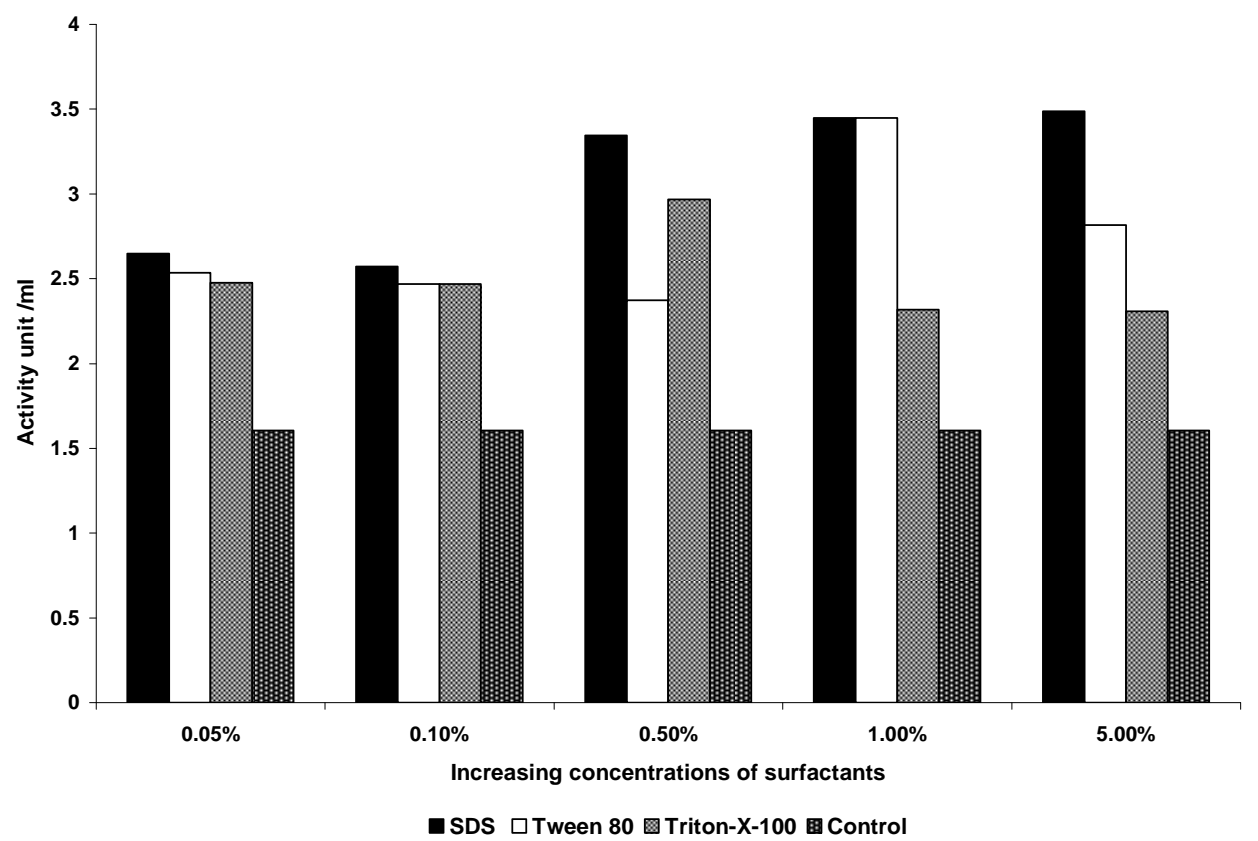

Figure 4. Effect of surfactant additions on the endo-1,4- $\beta$ glucanase activities of $T$. virens isolate PFHT9 
Table 2. Purification steps and yield of the endo-1,4- $\beta$ glucanase activities of $T$. virens isolate $P F H T 9$ from fermenting palm-fruit husk.

\begin{tabular}{|c|c|c|c|c|c|}
\hline Concentration method & $\begin{array}{c}\text { Total protein } \\
\text { (mg) }\end{array}$ & $\begin{array}{l}\text { Total activity } \\
\text { (nKat) }\end{array}$ & $\begin{array}{c}\text { Specific activity } \\
\text { (nKat/mg) }\end{array}$ & $\begin{array}{l}\text { Yield } \\
(\%)\end{array}$ & Purification fold \\
\hline Ammonium sulphate & 193.81 & 80.70 & 0.42 & 50.44 & 0.59 \\
\hline
\end{tabular}

The highest daily feed was consumed by the control diet birds (Table 3 ), while the least was by the birds maintained on the plain husk diet $(130.6 \mathrm{~g})$. There was no significant difference $(p>0.05)$ in daily bird weight gain, however, increase in bird weight was numerically highest for the birds maintained on the control feed $(15.14 \mathrm{~g} / \mathrm{day})$. The least feed/gain ratio was recorded from the husk diet without fungal inclusions. From Table 4, egg production and egg weight were significantly different $(\mathrm{P}<0.05)$ and numerically higher from the control diet. The least was from the husk diet without fungal inclusions. The albumen content was highest $(67.51 \%)$ from the control diet. The highest values recorded for the dry shell weight, wet shell weight and the shell thickness were from the microbially-modified palm-fruit husk-based diet (Table 5). This was followed by that from the control experiment and least from the husk diet without fungal additions. The dry shell weight was not significantly different when subjected to a one way ANOVA analysis. The results from the analysis of wet eggshell weight recorded the same pattern documented for the dry shell weight. There were significant differences in the shell thicknesses from the 3 tests $(\mathrm{p}<0.05)$. The highest quantity of yolk was recorded from the birds maintained on the diet of husk and T. virens (Table 6). The least was from the control diets. Egg cholesterol $/ 50 \mathrm{ml}$ egg weight was least with the un-modified husk diet fed on layers. That of the control birds was higher $(216.3 \mathrm{mg} / 50 \mathrm{ml})$ and the highest quantity of egg cholesterol was recorded in birds fed the microbially-modified experimental diet. By ANOVA, there was no significant difference in the yolk values, while there was for the egg cholesterol results. Non-parametric results showed a significant difference $(\mathrm{p}<0.05)$, in the yolk quantities between the husk diet with $T$. virens and the control diet.

Table 3. Performance of layer birds fed palm-fruit diets with and without microbial modification

\begin{tabular}{lccc}
\hline Diet & Feed consumption $\left(\right.$ g day $\left.^{-1}\right)$ & ${\text { Bird weight gain }\left(\text { g day }^{-1}\right)}^{\text {Feed / gain ratio (feed/ bird weight) }}$ \\
\hline Palm-fruit + T. virens & $134.57^{\mathrm{b}}$ & $14.71^{\mathrm{a}}$ & 9.15 \\
Palm-fruit - Fungus & $130.60^{\mathrm{b}}$ & $12.24^{\mathrm{a}}$ & 8.57 \\
Control maize diet & $150.0^{\mathrm{a}}$ & $15.14^{\mathrm{a}}$ & 9.91 \\
Probability of source of variation & & & 0.8776 \\
Husk addition & $\mathrm{P}<0.0001$ & 0.4824 & 0.6278 \\
Microbial addition & 0.0048 & 0.0013 & \\
Husk x microbe & &
\end{tabular}

*superscript shows grouping from t-test among the different feed types

Means within a column in each comparison group with no common superscripts differ significantly $(P<0.05)$

Means with the same letter are not significantly different $(P>0.05)$.

Table 4. Egg production, weight and albumen characteristics

\begin{tabular}{lccc}
\hline Diet & Egg production (eggs/bird d) & Egg weight (g) & \% Albumen \\
\hline Palm-fruit + T. virens & $0.713 \pm 0.05^{\mathrm{b}}$ & $59.91 \pm 0.82^{\mathrm{ab}}$ & $65.38 \pm 0.45^{\mathrm{ab}}$ \\
Palm-fruit - Fungus & $0.66 \pm 0.08^{\mathrm{b}}$ & $58.34 \pm 0.68^{\mathrm{b}}$ & $66.19 \pm 0.94^{\mathrm{a}}$ \\
Control maize diet & $1.385 \pm 0.02^{\mathrm{a}}$ & $61.18 \pm 0.09^{\mathrm{a}}$ & $67.51 \pm 0.35^{\mathrm{a}}$ \\
\hline \multicolumn{4}{c}{ Probability of source of variation } \\
\hline Husk addition & $<0.0001$ & 0.0062 & 0.2383 \\
Microbial addition & $<0.0001$ & 0.1759 & 0.0094 \\
Husk x microbe & 0.608 & 0.1975 & 0.465 \\
\hline
\end{tabular}


Table 5. Shell characteristics of poultry layer birds fed husk based diets with or without microbial additives.

\begin{tabular}{lccc}
\hline Diet & Dry shell weight (g) & Wet shell weight (g) & Shell thickness $(\boldsymbol{\mu m})$ \\
\hline Palm-fruit + T. virens & $9.54 \pm 0.26^{\mathrm{a}}$ & $11.01 \pm 0.3195^{\mathrm{a}}$ & $0.64 \pm 0.006^{a}$ \\
Palm-fruit - Fungus & $9.25 \pm 0.14^{a}$ & $10.74 \pm 0.1583^{\mathrm{a}}$ & $0.57 \pm 0.012^{c}$ \\
Control maize diet & $9.41 \pm 0.15^{\mathrm{a}}$ & $10.94 \pm 0.1125^{\mathrm{a}}$ & $0.60 \pm 0.003^{b}$ \\
\hline \multicolumn{4}{c}{ Probability of source of variation } \\
\hline Husk addition & 0.4779 & 0.3314 & 0.0015 \\
Microbial addition & 0.6758 & 0.8557 & 0.0454 \\
Husk x microbe & 0.3696 & 0.4784 & 0.0021 \\
\hline
\end{tabular}

Table 6. Yolk and cholesterol characteristics of poultry layer birds fed husk based diets with or without microbial additives.

\begin{tabular}{lccc}
\hline Diet & \% Wet yolk & \% Yolk solid & Egg cholesterol/ 50ml egg weight \\
\hline Palm-fruit + T. virens & $23.61 \pm 0.65^{\mathrm{a}}$ & $11.47 \pm 0.30^{\mathrm{a}}$ & $281.7 \pm 0.12^{\mathrm{a}}$ \\
Palm-fruit - Fungus & $23.07 \pm 0.79^{\mathrm{ab}}$ & $11.08 \pm 0.19^{\mathrm{ab}}$ & $205.4 \pm 0.022^{\mathrm{b}}$ \\
Control maize diet & $21.55 \pm 0.37^{\mathrm{b}}$ & $10.68 \pm 0.04^{\mathrm{b}}$ & $216.3 \pm 0.021^{\mathrm{b}}$ \\
\hline \multicolumn{4}{c}{ Probability of source of variation } \\
\hline Husk addition & 0.1331 & 0.0901 & $\mathrm{P}<0.0001$ \\
Microbial addition & 0.0333 & 0.0401 & $\mathrm{P}<0.0001$ \\
Husk x microbe & 0.6148 & 0.3208 & $\mathrm{P}<0.0001$ \\
\hline
\end{tabular}

\section{DISCUSSION AND CONCLUSION}

The genus Trichoderma has been known as a high producer of cellulases many of which have been characterized (18). The effect of $\mathrm{H}^{+}$concentration in reaction mixtures on enzymatic activities work in conjunction with other factors within the reaction mixture such as the ionization state of the enzyme, the enzyme-substrate complex and the molecular weights of the enzymes $(6,29)$. It was interesting to note that while fungal growth was most supported at $\mathrm{pH} 4.0$ and reduced as the $\mathrm{pH}$ range increased, the endo-1,4- $\beta$ glucanase recorded an activity peak at $\mathrm{pH} 6.0$ and had activity throughout all the $\mathrm{pH}$ ranges applied. This shows that the $T$. virens endo-1,4- $\beta$ glucanase has a broad range of $\mathrm{pH}$ activity, is $\mathrm{pH}$ tolerant and so may be employed in various industrial processes at all these ranges. Fungi are known to express enzymatic activities across a wide $\mathrm{pH}$ range and some retain activity through all.

Stability to temperature change is an important characteristic in enzymology and assists in the choice of the enzyme selected for industrial purposes especially those involving a high temperature step. Nagieb et al. (16), described a $T$. reesei cellulase with temperature stability up to $45^{\circ} \mathrm{C}$, a gradual loss to $60^{\circ} \mathrm{C}$ beyond which a rapid loss of activity occurred. The T. virens endoglucanase studied in this work was similar in that at $60^{\circ} \mathrm{C}$ and beyond no activity was recorded after 60 minutes and a sharp activity loss was consistently observed as incubation time increased. Temperature and $\mathrm{pH}$ were found to be important parameters which influenced enzyme activity. All these enzymatic responses would probably come into play in the successive colonization and the sequential degradation of structural plant polysaccharides (10, 24).

Metal ions possess either an inhibitory or stimulatory effect on microbial enzymes. On the endo-1,4- $\beta$ glucanase tested, the activation was most elicited by calcium and potassium ions. The activity of this enzyme cannot be said to be conclusively dependent on the presence of cations since two other divalent ions inhibited enzymatic activities. While some hydrolytic enzymes would require the involvement of divalent cations (5), others, like the activities of a Meloidogyne incognita reported by Bera-Maillert et al. (4) do not. All the surfactants used augmented the activities of the endo-1,4- $\beta$ glucanase enzyme. Surfactant enhancement was most exhibited through the addition of $1.0 \%$ SDS at all the concentrations enlisted. This was followed by that of Tween 80 and least by Triton-X-100. The endo-1,4- $\beta$ glucanase activities were 
improved by more than $43.75 \%$ of the control enzyme through the inclusion of surfactants to the reaction mixture. The reduction in surface tension, created by the addition of the different surfactants allowed more active sites on the CMC substrate for the endo-1,4- $\beta$ glucanase to bind to and as such improved the amount of reducing sugars generated. The endo$1,4-\beta$ glucanase specific activity and yield decreased at the ammonium sulphate step. Both increased, slightly and very sharply respectively at the column chromatography relative to the crude.

Animal experiment showed that feed consumption was best with the conventional feed and there was a significant difference between the quantity consumed by the test and control groups. Amongst the husk samples, feed consumption was numerically close and statistically insignificant. The slightly higher numerical value shows that the inclusion of the fungus assisted the layer birds in ingesting more feed quantities than they might have. The feed to gain ratio, however, showed the least feed quantity needed to record a $1 \mathrm{~g}$ increase in weight was from the unmodified palm-fruit husk modified diet. Interestingly, almost $10 \mathrm{~g}$ of feed intake was required to elicit a $1 \mathrm{~g}$ increase in body weight of the control birds maintained on the conventional diets. Increases in bird weights were not significantly different among test groups and also within the test and control groups. There was no significant effect of husk addition or microbial inclusions upon the bird weight gains studied. However, there was a highly significant difference of husk inclusion upon the quantity of feed ingested between the test and control bird responses. Non-parametric results of egg production and egg weight showed that best values were recorded from the control diet and there were no significant differences in husk treatments with and without microorganism $(p>0.05)$. There was, however, between the test and control experiments. Between the palm-fruit husk diets and the control, the results of the shell thickness showed there was a significant difference in favour of birds maintained on T. virens-modified diet. Microbial inclusions provided the highest eggshell thickness. The weights recorded for the eggshells in their wet and dried states did not demonstrate a significant statistical difference. The highest shell weight was obtained from the microbially-modified husk-fed layers. Microbial inclusion would obviously be beneficial from the values presented especially in terms of improving the final quality of the eggs sold to the consumers. A thick egg shell and weight would discourage easy breaking and cause more profit to be made by the farmer. Yolk parameters also showed that microbial inclusions afforded higher quantities of yolk. This is of great importance in human nutrition since the yolk is the most nutritive component of the poultry egg. The need to ensure food security and make enough maize substrate available for human nutrition instead of the constant competition between man and animals for the same nutritive substrate has caused research to focus on the effects of incorporating different concentrations of palm-kernel fibre into poultry diets. Ahmad (1) reported the recycling of products of palm-oil mill effluent into fertilizers and animal feed in order to maximize available resources and preserve the environment.

To the best of our knowledge, this is the first report on the complete incorporation of $T$. virens with the external husk component of oil-palm fruit into a poultry layer diet totally devoid of maize substrate. Since there was no significant difference in the bird weight values, and the feed to gain ratio were better with husk diets, the two husk treatments may be employed as substitutes for or partially incorporated into maize based diets in poultry layer nutrition. The husk diets might also generate 'earlier satiety' in birds such that excess maize is not ingested as a result of the compulsive pecking habits of the birds.

\section{ACKNOWLEDGEMENTS}

The authors are grateful to the authorities of the International Institute of Tropical Agriculture, Ibadan, Nigeria for the use of research facilities in the Germplasm Health Unit Laboratory. All national guidelines regarding the treatment, care and use of animals were strictly adhered to. 


\section{REFERENCES}

1. Ahmad, F. (2001). Sustainable agriculture system in Malaysia. Paper presented at the Regional Workshop on Integrated Plant Nutrition System (IPNS), Development in Rural Poverty Alleviation, United Nations Conference Complex, Bangkok, Thailand. P.18-20

2. Baker, J.O.; Adney, W.S.; Thomas, S.R.; Nieves R.A.; Chou Y.C.; Vinzant T.B.; Tucker M.P.; Laymon R.A.; Himmel M.E. (1995). Synergism between purified bacterial and fungal cellulases. In Saddler J. N., Himmel M. E.(eds.). Enzymatic degradation of insoluble carbohydrates. American Chemical Society Symposium Series 618. American Chemical Society, Washington, D.C., p. 113-141

3. Beguin, P.; Aubert, J.P. (1994). The biological degradation of cellulose. FEMS Microbiol. Rev., 13, 25-58.

4. Bera-Maillert, C.; Arthaud, 1.; Abad, P.; Rosso, M. N. (2000a). Biochemical characterization of M1-ENG1, a family 5 endoglucanase secreted by root knot nematode Meloidogyne incognita. Eur. J. Biochem., 267, 3255-3263.

5. Bera-Maillet, C.; Broussolle, V.; Pristas, P.; Giardeau, J.P.; Guidet, G.; Forano, E. (2000b). Characterization of endoglucanases EGB and EGC from Fibrobacter succinogenes, Bio. Biophys. Acta, 1476, 191-202.

6. Dixon, M.; Webb, E.C. (1971). Enzymes. Longman group Ltd. London. 67-188.

7. Food Chemical Codex National Academy of Sciences Food and Nutrition Board, (1981). Food Chemicals Codex 3rd Ed. Washington, DC: National Academy Press.

8. Gilkes, N.R.; Langsford, M.T.; Wakarchuk, W.W.; Kilburn D.G.; Miller R.C.; Warren R.A.J. (1984). The cellulase system of Cellulomunas finni. J. Gen. Microbiol. 130, 1367-1376.

9. Howard, R.L.; Abotsi, E.; Jansen van Rensburg, E.L.; Howard, S. (2003). Lignocellulose biotechnology: issues of bioconversion and enzyme production. Afr. J. Biotechnol, 2, 602-619.

10. Li, X.; Gao, P. (1997). CMC-liquefying enzyme, a low molecular mass initial cellulose-decomposing cellulase responsible for fragmentation from Streptomyces sp. LX. J. Appl.Microbiol. 83, 59-66.

11. Lowry, O.H.; Rosebrough, N.J.; Farr, A.L.; Randall, R.J. (1951). Protein measurement with the Folin Phenol reagent. J. Biol. Chem. 193, $265-$ 275.

12. Malherbe, S.; Cloete, T.E. (2003). Lignocellulose biodegradation: fundamentals and applications: A review. Environ. Sci. Biotechnol. 1,105-114.

13. Mansfield, S.D.; Saddler, J.N.; Gubitz, G.M. (1998). Characterization of endoglucanases from the brown rot fungi Gloeophyllum sepiarium and Gloeophyllum trabeum. Enz. Microbiol. Technol. 23, 133-140.

14. Milala, M.A.; Shugaba, A.; Gidado, A.; Ene, C.; Wafar, J.A. (2005).
Studies on the Use of Agricultural Wastes for Cellulase Enzyme Production by Aspegillus niger, Res. J. Agric. Biol. Sci. 1(4), 325-328.

15. Miller, G.L. (1959). Use of dinitrosalicylic acid reagent for determination of reducing sugars, Anal. Chem., 31, 426- 428.

16. Nagieb, Z.A.; Ghazi, M.; Kassim, E.A. (1985). Studies on cellulase from Trichoderma reesei and its effect on pretreated cellulosic materials, $J$. Appl. Polymer Sci. 30, 4653-4658.

17. National Organic Standards Board (NOSB) 1999. Enzymes, Plant and Fungal.

18. Nevalainen, H.; Penttila, M. (1995). Molecular biology of cellulolytic fungi In: (Esser, K., Lemke, P.A.(eds). The mycota: genetics and biotechnology. Springer-Verlag KG, Berlin, Germany, p.303-319.

19. Qi, M.; Jun, H.; Forsberg, C.W. (2008). Cel9D, an Atypical 1,4- $\beta$-DGlucan Glucohydrolase from Fibrobacter succinogenes: Characteristics, Catalytic Residues, and Synergistic Interactions with Other Cellulases, $J$ Bacteriology, 190(6), 1976-1984 .

20. Reese, T.; Maguire, A. (1969). Surfactants as Stimulants of Enzyme Production by Microorganisms. J. Appl.Microbiol. 17, 242-245.

21. Robson, L.M.; Chambliss, G.H. (1984). Characterisation of the cellulolytic activity of a Bacillus isolate. Appl. Env. Microbiol. 47(5), 1039-1046.

22. Rose, J.K.C.; Bennett, A.B. (1999). Cooperative disassembly of the Cellulose-Xyloglucan Network of plant cell walls: Parallels between cell expansion and fruit ripening Trends Plant Sci. 4, 176-183.

23. Rudsander, U.J. (2007). Functional studies of a membrane-anchored cellulase from poplar. Stockholm Royal Institute of Technology, School of Biotechnology, Department of Wood Biotechnology, AlbaNova University Center School Sweden.

24. Schwarz, W.H. (2001). The cellulosome and cellulose degradation by anaerobic bacteria. Appl. Microbiol. Biotechnol. 56, 634-649.

25. Tribak, M.; Ocampo, J.A.; Garcia-Romera, I. (2002). Production of xyloglucanolytic enzymes by Trichoderma viride, Paecilomyces farinosus, Wardomyces inflatus, and Pleurotus ostreatus, Mycologia, 94, 404-410.

26. Van Soest, P.J. and Wine R.H. 1967. Use of detergents in the analysis of fibrous feeds. IV. The determination of plant cellwall constituents. Journal of the AOAC 51, 780 .

27. Yeoh, H.H.; Khew, E.; Lim, G. (1985). A simple method for screening cellulolytic fungi. Mycologia, 77, 161-162.

28. Zeffere, E.; Hall, P.L. (1973). The study of enzyme mechanisms. John Wiley and Sons. N.Y. London.

29. Zhou, S.; Ingram, L.O. (2000). Synergistic hydrolysis of carboxymethylcellulose and acid-swollen cellulose by two endoglucanases (celz and cely) from Erwinia chrysanthemi, J. Bacteriol. $182,5676-5682$. 